\title{
КООРДИНАТИ ПАМ'ЯТІ Й ІСТОРІЇ ОКОЛИЧНОГО ПРОСТОРУ ВАЛЕРІЯ ШЕВЧУКА
}

\section{Грищенко О. В.}

\section{ВСТУП}

Урбанізм дає чітке уявлення про життя людини у великому місті, пояснює іï вчинки, орієнтує на майбутнє. Більшість сучасних українських прозаїків звертається до життя великого міста, акцентує увагу на різних локусах, що впливають на світогляд людини. Для прози Вал. Шевчука характерний відхід від усталеної традиції. Письменника насамперед цікавить життя в невеликому місті та людина, яка повноцінно облаштовується в провінційному середовищі, iіi самореалізація, здобутки й утрати. Як зазначає Л. Вірт, якщо провінційна місцевість через контакт і комунікації потрапляє під вплив міста, то на неї накладається відбиток урбанізації. «Урбанізм з'являється скрізь, куди доходить міський вплив» ${ }^{1}$.

Аналізуючи провінцію як місце досвіду, М. Гайдеггер дійшов висновку, що це світ, що через працю розкриває свій простір. В умовах околичного простору Вал. Шевчук пізнає людину, ii духовну наповненість. Простір такого середовища постає своєрідним мікрокосмом, власним естетичним світом, буттям та існуванням.

У прозі Вал. Шевчука важливою $є$ трансформація від центрального до периферійного, від великого до малого, від міського до провінційного. Для творчості письменника характерна орієнтація на простір маленького містечка. Через це в митця фігурують вулиця, міст, халабуда, подвір'я, сад як окремі образи твору. Особливого значення надається дому як живій істоті. Околичний простір Вал. Шевчука - це Всесвіт, у якому перетинаються координати пам'яті та історії, що з розумінням художнього твору набувають нових сенсів і значень.

Сповідуючи філософські наративи, багатогранна творчість Вал. Шевчука привертає увагу дослідників до осмислення нового розвитку сутнісного, найважливішого. Так, до аналізу творчості Вал. Шевчука зверталися В. Балданюк (авторський наратив), Н. Беляєва (історичний контекст), Т. Блєдних (бароковість), В. Власенко, Г. Врублевська (лінгвостилістичний аспект), А. Горнятко-Шумилович

${ }^{1}$ Wirth L. Urbanism as a way of life. The American journal of sociology. 1938. Vol. 44. P. 1-24. 
(концепт химерності), Н. Городнюк (семіотичний код), Л. Донченко (міфологізм), Л. Залеська-Онишкевич (вистави за творами автора), О. Солецький (пам'ять) та ін.

\section{1. Таємниці околичного простору}

Основні локусу подій у творчості письменника - це рідний Житомир, його околиці, київські простори. Повертаючись до своїх попередніх тем, письменник вражає різноманіттям інтерпретацій, оригінальністю, яскравою образністю. У романі «Стежка в траві. Житомирська сага» Вал. Шевчук уже промовистою назвою натякає, що події роману відбуватимуться в межах Житомира чи його околиць. Автор подає розлогу панораму українського життя середини XX століття.

Для інтерпретації змальованого в «Житомирській сазі» світу дитинства важливий образ мосту, з яким пов'язано безліч думок, спогадів, радощів i прикрощів, як у героїв твору, так i самого письменника. «Моя хата стоїть біля мосту, через це всі мої спогади про дитинство - це спогади про міст. 3 одного його боку після війни стояла пивниця, біля неї - вкопані дерев'яні стовпчики, до яких візники прив'язували коней» ${ }^{2}$. Вал. Шевчук зображає міст у містичнозагадковому ключі: розповідає історію сімейної пари, котрій не вдалося перейти мосту, або історію 3 військовим бронетранспортером, який розвертався й, не розрахувавши, зламав дерев'яні перила мосту й звалився у воду. «Тоді вперше я подумав, що наш міст мстивий. Що він не тільки дає змогу перейти чи переїхати через прірву, а що він ту прірву часом підгодовує, бо скільки можна мнути його колесами чи топтати ногами» ${ }^{3}$. Незважаючи на трагічність подій, Вал. Шевчук архітектурну конструкцію називає дивовижним мостом життям. Така привілейованість зумовлена активною участю мосту в житті дорослих і дітей. У романі міст - це місце відпочинку, гри, бешкетування, міст, що говорить про людські інтереси, заняття, тривоги, турботи; це символ безтурботного дитинства, 3 яким пов'язано пам'ять дитячих пригод, думок, почуттів.

Ідеальний образ Дому в «Житомирській сазі» постає в інтерпретації Сильвестра, який у свідомості вимріяв ідеальні родинні стосунки, сімейне тепло, родинний затишок. Перебуваючи в екстремальних умовах концтабору, Сильвестр марить домашньою ідилією, тому й відсилає додому п'ять листів-віршів, у яких розповідає про власне бачення домашнього затишку, незважаючи й на певну дивакуватість.

${ }^{2}$ Шевчук В. Стежка в траві. Житомирська сага : у 2 т. Харків : Фоліо, 1994. T. 1. C. 85 .

${ }^{3}$ Там само. С. 93. 
Спостерігаючи за апологією рідного дому у творчості Вал. Шевчука, Р. Корогодський зазначає, що Сильвестр є «свідомим носієм ідеї дому як єдиного духовного осередку, можливого захисту душі від суспільної ерозії, агресії» ${ }^{4}$

Осмислення життєвого плину як незбагненної загадки дало поштовх до зацікавлення автора вуличним життям, де чітко розмежовується «свій» та «чужий», ставлення до добра та розуміння реальної сили зла. На прикладі Віталія Волошинського, головного героя роману, автор стежить за складним становленням особистості героя, який ніби 3 дитячих років розумів закони вуличного життя, намагаючись пізнати істину. На світогляд Пепи, «друга» Волошинського, вплинула вулиця, тому він і ставить Віталію умови стосунків і підштовхує його до злочинних намірів.

У житті героїв вулиця - простір, у якому зіштовхуються опозиції добро/зло, високе/низьке, духовне/матеріальне. Згадані Вал. Шевчуком вулиці (Трипільська, Старовільська, Левківська, Бердичівська тощо) апелюють до історичного Житомира, що зберіг у собі залишки старожитностей. Просторовий концепт, що відчутний у романі, відбиває національне світовідчуття автора. Вал. Шевчук пише про рідні місця, естетично розкриває привабливість маленької батьківщини Житомирщини. «Інколи кричав десь півень, часом гавкав собака, вряди-годи сокотіли кури, крякали, бува, качки, подеколи зносився жіночий голос чи гукала мати дитину. Мекала коза, журкотіла річка, шелестіло листя прибережних дерев - усе це були звуки Тиші, яка й поселяється по таких долинах» ${ }^{5}$.

Мотив вуличного життя наскрізний у творчості Вал. Шевчука. Простір вулиці функціонує як у ранній, так і в зрілій прозі митця. У текстах письменника вулиця слугує більше тлом, де відбуваються різноманітні історії звичайних людей. «Роман юрби» (2009) щонайкраще презентує означену ідею, тут зображено історії людей 3 однієї вулиці. Письменник у романі постає майстерним спостерігачем, котрий зафіксував найцікавіші моменти з власного життя.

За авторським визначенням, «Роман юрби» - це хроніка «безперспективної» вулиці, що відтворює широку панораму українського життя XX століття. Композиційно «роман» складається 3 шістнадцяти оповідань і невеликих повістей, де кожна історія із життя вулиці постає окремим художньо довершеним твором. Цікава тут роль

\footnotetext{
${ }^{4}$ Корогодський Р. Втеча від самотності, або Апологія рідного дому. Шевчук В. Стежка в траві. Житомирська сага : у 2 т. Харків : Фоліо, 1994. Т. 1. С. 17.

5 Шевчук В. Стежка в траві. Житомирська сага : у 2 т. Харків : Фоліо, 1994. T. 2. C. 310 .
} 
головних і другорядних героїв, котрі залежно від оповіді з'являються в різному амплуа, переходячи 3 одного твору в інший. Хроніка «безперспективної» вулиці - це результат довгорічних спостережень автора за добре знайомим світом. Вал. Шевчук зображає світ і створює власну філософію людини й людства, у якій визначальною $є$ жага пізнання світопорядку.

У «романі» вулиці надається одне 3 основних значень як центральному місцю околиці. Саме тут можна дізнатися останні новини від своїх сусідів чи знайомих, але більше зацікавлення надається новинам приватного, інтимного життя. Крім того, вулиця зберігає пам'ять про своїх мешканців. У художньому баченні письменника вона постає затоптаною людьми й транспортом, запиленою, місцями нерівно викладеною бруківкою, побитою вибоїнами. Повертаючись на рідну вулицю, герої занурюються у вир спогадів дитинства. Вона відсилає до уявного повернення в минуле, оновлюючи в їхній пам'яті пережиті події. У такому стані герої почуваються радісно, але переповнюють їх хвилювання та сум. На думку П. Хаттона, місце, що визначає стадії власного шляху, функціонує як мнемонічне, тобто слугує фоном для дивовижної медитації, задуми. Найбільшою мірою зв'язок між пам'яттю та минулим, на думку дослідника, пояснює автобіографія. «Вона захоплювала дорослого назад, до витоків його життя, повідомляючи усвідомлений вираз імперативом самоаналізу» ${ }^{6}$. Автобіографічне самопізнання сприяє виникненню уявлень про розвиток «Я». Науковець переконаний, що використання автобіографічного характеризує історію формування кожного індивіда. Герої Вал. Шевчука, які піддаються спогадам, оновлюють зв'язок витоків власної ідентичності, тобто повертаються у світ натхнення, світ дитинства.

Герої не лише спостерігають за власним і сусідським життям, а й вихоплюють із вуличного простору його барви, насолоджуються його красою. Вони піддаються сентименту, але разом із тим уважають за можливе піднести свою вулицю до найбільш довершених форм простору. Найпривабливіше вулиця у Вал. Шевчука виглядає навесні, коли все квітне та наповнюється яскравими кольорами. Переживаючи любовну трагедію, Льонька хоче забути всі негаразди, споглядаючи вуличний простір. «Самі дерева ясно зеленіли, здавалося, струмує з них чисте сяйво. Хати по обидва боки вулиці топились у білому молоці цвіли вишні і розквітали яблуні. Готові були спалахнути й груші хвилі тонкого аромату висіли в повітрі, начебто хто напарфумував

${ }^{6}$ Хаттон П. История как искусство памяти. Санкт-Петербург : Владимир Даль, 2004. C. 370 . 
околицю» ${ }^{7}$. М. Гайдегтер свого часу акцентував увагу на тому, що зі зміною пір року змінюється й радість бачення світу. Мандруючи вулицею, Льонця долучається до радісних моментів життя, а «радість бачення - ворота, що вказують до вічного» ${ }^{8}$.

Основним місцем зустрічі для всіх посиденьок $\epsilon$ камінь край дороги. Саме тут герої обмінюються думками, спростовують/підтверджують власні сумніви, вступають у суперечки, обговорюють життя сусідів. «Це був особливий камінь, сюди тягло на посиденьки цілий куток» ${ }^{9}$. По суті, камінь - це серцевина вулиці, що збирає довкола себе максимальну кількість мешканців околиці. Це iï символ, якому властивий дух пережитих подій, а також зібрана інформація, що накопичувалася роками.

Довершеним постає й сам образ околиці. Зображення околичного простору напрочуд пов'язано з мотивом дороги. Ідучи стежкою, герої роману деталізують провінційне середовище. Так, Йонта спостерігає за озелененням городу, тополями, річкою, греблею, затишною лавочкою, де «любили посидіти й жителі околиці, й заблуклі закохані, де їх удосталь обсипало тополиним пухом і де вирішувалися важливі, на все життя, справи: укладалися угоди, або ж розливалися сльози» ${ }^{10}$. Через сприйняття мешканцями околичного простору моделюється пейзаж, природний світ, уявляється ідеальне місце проживання. Якщо Йонта споглядає внутрішній простір, то інший герой, Швець, візуально осягає весь простір околиці 3 найвищої іiі точки - гори. Мотив дороги розширює простір околиці. Ї̈̈ відокремлення від урбанізованого життя створює різкий контраст між двома населеними пунктами. Для міста характерний технологічний розвиток, креативність, створення артпроектів, для околиці - тиша, спокій, звичайність. М. Гайдеггер уважає, що під звичайністю криється вражаюча таємниця, де варто уникати одноманітності. «Звичайність нескладного зберігає всередині себе істину загадки всього великого та неминучого... У непомітності постійно одного й того ж звичайне приховує власне благословення» ${ }^{11}$.

7 Шевчук В. Роман юрби: хроніка «безперспективної» вулиці (1972-1991) / передм. Л. Тарнашинської. Київ : Унів. вид-во ПУЛЬСАРИ, 2009. С. 189.

8 Хайдеггер М. Проселок. Исток художественного творения : избранные paботы разных лет / пер. с нем. А.В. Михайлова. Москва : Академический проект, 2008. C. 394.

9 Шевчук В. Роман юрби: хроніка «безперспективної» вулиці (1972-1991) / передм. Л. Тарнашинської. Київ : Унів. вид-во ПУЛЬСАРИ, 2009. С. 30.

${ }^{10}$ Там само. С. 54

11 Хайдеггер М. Проселок. Исток художественного творения : избранные pаботы разных лет / пер. с нем. А.В. Михайлова. Москва : Академический проект, 2008. C. 393. 
Прогулянка околицею та осягнення їі простору для обох героїв є нічим іншим, як надбанням прекрасного.

Околиця у Вал. Шевчука - це долина, розташована недалеко від урбанізованого життя. «Стоїть на горі й бачить долину, куди має спуститися. Через річечку перекинуто моста, по ньому мчать авта, річка крутить слизьке тіло, між безлічі кам'яних брил, перетягується де-не-де кам'яною гребелькою, наче паском, - недаремно вона Кам'янка. Нижче, за мостом, мурована гребля зі шлюзом, зліворуч густі корони дубів, і між тих дубів топиться мала і неймовірно рідна хатина» ${ }^{12}$. Привабливою вона постає й у сутінках, уночі. Зображаючи нічне середовище, Вал. Шевчук вдається до традицій казки, коли тварина уособлює якесь явище. У письменника це невидимий птах, який, прилітаючи із настанням сутінок, спонукає різноманіття квітів віддати свій аромат, а героїв - відчути спокій, радість, відпочити після важкої праці. «Тоді спускається до них невидимий птах. Великоокий та лагідний, він сідає біля них і спокійно дивиться на світ. Його крила пахнуть матіолами, і це він приніс у долину вечірній спокій. Навколо тепла тиша, м'який, блідий і синій серпанок, і хоч птах уже спустився, в повітрі чути посвист його крил - співають цвіркуни» ${ }^{13}$. Казковими елементами наділено околичний світ і вночі. Місяць та зорі діють на земний світ наче магія, адже містичним чином прокидаються рослини. «Напливала на околицю ніч... висівали на землю останнє насіння бур'яни; тягли колючки лопухи, щоб зачепитися за одежу перехожого чи за хвіст блудящого пса; витягала свої вильця собача кропива - десь біля греблі монотонно шуміла вода, збиваючи шум, і клапті того шуму пливли, як вата, по воді» ${ }^{14}$.

\section{2. Дім - місце історії та пам'яті}

Модель околиці у Вал. Шевчука - це ії розташування біля міста, на тлі природи, біля річки, у долині під горою. Серед таких краєвидів і розташований дім, що в «Романі юрби» набуває різних конотацій. Це й химерний, старовинний дім, дім як гавань, як мотиватор до спогадів, дім-істота, дім-мушля, антидім.

Залежно від оповіді дім трансформується під своїх героївмешканців, викликаючи в них різні почуття й емоції. Тому герої автора полюбляють згадувати батьківський дім, прокручуючи у свідомості (ефект кіноплівки) приємні спогади. Крім того, образ будинку мотивує

12 Шевчук В. Роман юрби: хроніка «безперспективної» вулиці (1972-1991) / передм. Л. Тарнашинської. К. : Унів. вид-во ПУЛЬСАРИ, 2009. С. 71.

${ }^{13}$ Там само. С. 88.

${ }^{14}$ Там само. С. 146. 
героїв до пригадування минулого життя. Достатньо лише побувати в одній із кімнат і пірнути в спогади. У ностальгічному стані герої почуваються щасливими, а зовнішній світ стає ближчим до власного внутрішнього, рідним і дорогим, чітким і злагодженим. Лише в домігавані герої прощаються 3 внутрішньою вичерпністю, порожнечею, натомість отримують спокій i прихисток. Шевчуковий дім $\epsilon$ локалізованим місцем, від постійного споглядання якого в пам'яті виникають нові деталі з минулого.

Зображення дому як істоти цілком традиційне у творчій спадщині письменника. На думку Вал. Шевчука, постійні сварки та колотнечі в будинку зумовлюють його поділ навпіл, спричиняють утрату ідилії. Зі слабшою стороною в сварці помирає й частина будинку. Тоді він стає антидомом, нещасливим помешканням, внутрішній простір якого наповнюється холодом, стає чужим і немилим, а зовнішній світ стиглістю, печаллю, сльозами. У такому домі герої відчувають власну поразку та жалюгідність своєї особистості. Коли будинком Степана Карташевського заволодів тріумвірат (жінка, дочка та зять), герой відчув ганьбу поразки. Світ і будинок сприймаються тепер чужими, навіюючи смуток і печаль. «Отож кинув поглядом у небо, прозоре, вицвіле, без жодної хмарини, і не знайшов на чому опертися окові. Позирнув і на дорогу, але й вона була порожня й синя. Тоді по тілу його перебіг дрож, i він, заплющивши очі, подумав, що не тільки дурний, як це визначила його жінка, а, можливо, й жалюгідний. Що він жебрак, який підійшов до чужого дому, простягши руку, і великодушна господиня того дому, кривлячись од жалю й огиди, несе йому милостиню» ${ }^{15}$.

Інколи дім набуває містичних рис. Його сприйняття залежить від місячного освітлення, нагадуючи казкову хату на курячих ніжках. Лише 3 настанням ранку містична хата набуває свого попереднього/ традиційного вигляду. Містичним видається й помешкання, у якому порожньо. Саме так свій дім ідентифікує Вася Равлик, коли споглядає порожній двір і дім. Це образ героя-самітника, що «замуровує» самого себе у власній хатці. У великому світі Вася почувається самотнім і відстороненим від соціуму, не приймаючи ідеалу сімейного життя. Жити самому - найзручніший момент існування, «адже не бувало ще такого, щоб ув одній хаті жили аж два равлики» ${ }^{16}$. Лише 3 появою в житті героя жінки його існування набуває сенсу. Для Васі це ніби свято, казка або дивна та незрозуміла, незвичайна річ. Уникаючи суспільства, герой Вал. Шевчука ховається у своєму домі-мушлі або

15 Шевчук В. Роман юрби: хроніка «безперспективної» вулиці (1972-1991) / передм. Л. Тарнашинської. Київ : Унів. вид-во ПУЛЬСАРИ, 2009. С. 308.

${ }^{16}$ Там само. С. 423. 
занурюється у внутрішньому світі. Як зазначив Г. Башляр, мешканці мушель - це «змішані», проміжні істоти, які приречені на знищення вищим життям. Дім-мушля є для слабкого героя міцним захистом від навколишнього середовища, сусідів, зіпсованого настрою. «Ті дві вуличні пащекухи говорили бридоту зумисне аж так, щоб Вася їх почув. Отож він сховав ріжки і втягнувся у свою хату, і ладен був замуруватися в неї навіки, бо все ще палав - ладен був підпалити тим вогнем увесь дім i самоспалитись» ${ }^{17}$. Такий дім Г. Башляр називає первинним образом, непорушним, «це надбання незмінного пасажу старожитностей людської уяви» ${ }^{18}$. Крім того, мушля функціонує в романі не лише як дім, а і як уявна оболонка, за якою приємно ховати внутрішнє єство. Вал. Шевчук не вдається до опису мушлі як такої. Образ Васі Равлика - це символ завершеності/деградації людської істоти, причому ознаки людськості $\epsilon$ мінімальними. Це герой, який наділений комплексом страху перед великим світом.

Цікавий образ Дому фіксуємо й у романі «Привид мертвого дому» (2005), що композиційно складається 3 п'яти невеликих оповідок про життя людини на околиці. У першій оповіді під назвою «Привид мертвого дому» Вал. Шевчук закодовує ідейне навантаження всієї книжки, що, за спостереженнями Раїси Мовчан, убачається у двох константах: минуле, що переслідує людину протягом усього ії життя, та ідея «мертвого дому».

Перша частина (хол) перейнята ностальгією за минулим і домівкою. Як і в «Набережній, 12», тут Вал. Шевчук удається до зображення образу Дому як мікрокосму, маленького Всесвіту, де життя мешканців одного будинку переплетене різними химерами. Будинок цей іноді ніби вихоплює із життя душі своїх мешканців. Письменник, власне, створив міф про будинок, що заволодівав душами, порушивши тим самим проблему духовного єства, вищої сили. Авторська інтерпретація міфу оволодіння людськими душами пов'язана 3 минулим: із часами «до створення світу» або «на початку часів». Міфотворчість Вал. Шевчука перетворюється на відображення соціальних структур, суспільних відносин і ставлення людини до уявлень про Бога.

Крім того, старий будинок уособлюється і як жива істота, котрій притаманні людські якості. Містичному помешканню властивий розум, що 3-поміж мешканців обирав жертви. «Йому [будинку] надходила пора вмирати й перетворитися згодом у привида, але знав він інше:

17 Там само. С. 452.

18 Башляр Г. Избранное : Поэтика пространства / пер. с фр. Н.В. Кисловой, Г.В. Волковой, М.Ю. Михеева. Москва : Российская политическая энциклопедия (РОССПЭН), 2004. С. 62. 
коли нищитиме пожильців тої чи іншої квартири повністю, то так йому спокійно не вмерти, бо на звільнене місце прийдуть пожильці нові, легше ж йому буде, коли люди не змінюватимуться, а умалюватимуться частково й поступово. Отож він почав вихоплювати 3 тієї чи тієї родини по одному» ${ }^{19}$. Важливо, що після кожної смерті з'являється портрет померлого як пам'ять його існування в цьому домі. 3 усіх творінь Георгія Ковальчука найбільш удалими є портретні зображення. За допомогою живопису герой дублює світ, а разом із ним і його жителів. С. Зонтаг уважає, що дублювання світу відбувається в той момент, коли людський ландшафт із запаморочливою швидкістю піддається змінам. «За короткий проміжок часу руйнується незліченна кількість форм біологічного та соціального життя, тому й виникає пристрій, здатний закарбовувати образ зникомого» ${ }^{20}$. Призначення Ковальчука - підтримувати зв'язок між померлими і живими. Портрети померлих мешканців містичного будинку єднають із минулим.

Найбільш зображення образу Дому суголосне із самим оповідачем, який сприймає життя в ньому через власне дитяче бачення. Спостерігаючи за будинком, його мешканцями, оповідач починає розуміти таємниці старої споруди. Герою відкриваються закони життя: пізнаючи щось, людина знову народжується 3 новими набутками, але тим самим наближується до фіналу. Осягаючи простір життя, геройоповідач народжується як дорослий чоловік, натомість прощається 3 дитинством і юнацтвом. Саме в дорослому віці його не покидають думки про батьківський дім. «Недарма він, той мертвий дім, не покидає мене і сидить у мені, як забитий у серце цвяшок. Недаремно й ті люди приходять до мене в мої сни і в мої яви й турбують: що вони від мене хочуть чи вимагають? Того не знати, але в спокої мене не полишають» ${ }^{21}$. Письменник наголошує на важливості батьківського дому, його ролі в дорослому віці. Незалежно від місця проживання людина піддається спогадам про родинне помешкання. Навіть серед деталей навколишнього середовища дім постає перед героєм порізному: то зависає в повітрі, проявляється в просторі, наче на фотоплівці, з'являється в мініатюрі на долоні, спускається зі стелі або видніється серед хмар. Минуле впливає на теперішнє та майбутнє життя. Герой стверджує: «Минуле своє ми покидаємо у прірві часу й гадаємо, що воно навіки безповоротне, тому й мертве, та це жахлива

19 Шевчук В. Привид мертвого дому : роман-квінтет. Київ : Унів. вид-во ПУЛЬСАРИ, 2005. С. 81.

${ }^{20}$ Сонтаг С. О фотографии / пер. с англ. В. Голышева. Москва : Ад Маргинем Пресc, 2013. С. 28.

21 Шевчук В. Привид мертвого дому : роман-квінтет. Київ: Унів. вид-во ПУЛЬСАРИ, 2005. С. 98. 
наша помилка, бо мертві ми стаємо тоді, коли те минуле вмирає, а поки воно $\epsilon$, то й ми $\epsilon$, поки ми живі, то й воно живе» ${ }^{22}$.

Навколишній простір надзвичайно важливий у житті Шевчукових героїв. Залежно від простору змінюється їхня поведінка, настрій, думки, часом і мета існування. Простір бульвару з другого холу «Зачинені двері нашого «Я» впливає на головного героя, дозволяючи поміркувати над зробленими вчинками. Закритий же простір підвального приміщення підштовхує до розваг та ігор, які в кінцевому результаті перекваліфіковуються в неподобства та крадіжки. Дитяче сприйняття простору негативно вплинуло на світогляд дорослого героя, адже простір закритого помешкання, дому Максим асоціює 3 домом-коробкою, домом-ніркою, домом-кліткою. Простір великого міста діє на героя гнітюче, внутрішне «Я» притлумлюється зовнішніми чинниками. Максимова душа стає порожнечею, пусткою, через що, відповідно зникає й зацікавлення великим світом. «Мені бракувало повітря, холодний вітер гуляв по всьому тілові, видуваючи 3 нього рештки тепла, і я також ставав порожній, як ця вулиця між цвинтарних мурів і той трамвай, що червоно котився по рейках ${ }^{23}$. У пригніченому стані дім сприймається героєм як коробка, що позбавлена довершеності, затишку, родинного тепла. Натомість надалі Вал. Шевчук вдається до зображення дому-хаосу, захаращеного безліччю різноманітних речей, що перешкоджає Максимові віднайти свій затишок.

Довершеним у світосприйнятті Максима постає саме відкритий простір. Під час прогулянок київськими парками герою краще думається, краще згадується дитинство. Осягаючи простір, герой уносить різноманіття у своє життя. Герой зізнається: «Коли пройдуть вересневі дощі й природа зробить оту перекличку з тепла на холод, коли знову з'явиться сонце, але то вже буде інакше сонце, наливатиме листя своєю барвою, і воно зацвіте, запалахкотить, - саме тоді найліпше й блукається алеями київських парків» ${ }^{24}$. Не уникає Вал. Шевчук і привабливих описів великого міста. Постійне пересування вулицями Києва автомобілів і трамваїв, миготіння світлих i яскравих кольорів створює ефект міста-калейдоскопа, якому властивий рух, швидкість, забарвленість тощо.

Світ природи помітніший у просторі околичного життя, що приваблює запахами трав і квітів, відкритим небом, запаморочливим купанням у річці чи озері. Вал. Шевчук наголошує на ідилії, що, за М. Гайдеггером, можлива лише в провінційному світі. «I от сталося

22 Шевчук В. Привид мертвого дому : роман-квінтет. Київ : Унів. вид-во ПУЛЬСАРИ, 2005. С. 123-124.

${ }^{23}$ Там само. С. 172.

${ }^{24}$ Там само. С. 178. 
диво... без особливих труднощів напитала хату на околиці села, яку можна було зняти на місяць, - 3 одного боку був сосновий ліс, а 3 другого - придніпровські луги, безмежні й безлюдні, за п’ять кілометрів - Дніпро, а на луках - чудові чисті озера, де завжди стримить кілька понурих рибалок» ${ }^{25}$. Осягнення ідилічного життя складне для Шевчукових героїв. Тут важливо відокремитися від великого світу й досягти максимального внутрішнього спокою. Не без містифікації Вал. Шевчук вдається до діалогу між людиною та довкіллям. Для його героїв вартісним є розуміння світу, чи міського, чи провінційного. Звертаючи увагу на деталі довколишнього світу (драглисту зелень сутінок, придніпровські луги, птахів, дерева), герої письменника відкривають для себе нове життя, наповнюючи його силою природи. «Я відчував, що таки вилікувався від своєї нудьги, що мені на певний час вдалося врятуватися, що я певною мірою відновив у собі здатність милуватися чи вражатися світом, отже, можу повертатись до людей, у звичне коло дій і справ» ${ }^{26}$.

Логічним продовженням другої частини $є$ наступна - «Сім тітоньок великого музиканта», де провінційний світ для головного героя значно важливіший за велике богемне місто. Як і в попередній частині роману, характерними тут $\epsilon$ мотив дому, а також старого саду та маленького містечка.

У розповіді про музиканта Станіслава, який приїздить у невелике рідне містечко, Вал. Шевчук подає контраст між двома світами. Світ великого міста - це хаос переживань героя, постійні зустрічі, безкінечні участі в різноманітних заходах, гастролі. У цьому світі герой реалізується професійно, будує кар'єру відомого й поважного музиканта, стає професором консерваторії. Натомість жертвує особистим життям, духовно спустошується. Швидкий темп життя великого міста наштовхує героя на роздуми про «Я» у світі. Постійна метушня, зустрічі, мистецькі акції, концерти, щоденна праця над музичними творами спричинили розкол життя героя, фізичну та духовну недостатність. Перебуваючи фізично в Києві та займаючись професійними справами, Станіслав «не належав сам собі» ${ }^{27}$. За визнання в суспільстві герой приречений платити самотністю. Лише незначні втечі від примарливого світу дають можливість духовного збагачення, де звичайні речі щоденного вжитку для героя набувають

25 Шевчук В. Привид мертвого дому : роман-квінтет. Київ : Унів. вид-во ПУЛЬСАРИ, 2005. С. 262.

${ }^{26}$ Там само. С. 267.

27 Шевчук В. Привид мертвого дому : роман-квінтет. Київ : Унів. вид-во ПУЛЬСАРИ, 2005. С. 295. 
нового (при)значення. На думку М. Гайдеггера, у житті великого міста людина 3 легкістю може залишатися напризволяще, самотньою, але не відає усамітнення. Знайти усамітнене місце можна лише в провінційному середовищі, що наділене особливою силою.

Приїзд героя додому до провінційного містечка ознаменовано як данину рідним, і тут герой черпає життєдайну духовну силу. Рідне місто заклало в Станіславові творчий потенціал генія, збудувавши тим самим міцний фундамент творчого зростання. Саме тому джерело натхнення герой асоціює з рідними місцями.

Головними в провінційному житті героя є три речі: дім, старий сад i родина. Старий будинок постає частиною душі Станіслава, як «гавань для втікача» ${ }^{28}$. У будинку, де проживали тітки, Станіслав приймав власне опрощення, повертався мріями в дитинство, до фатального кохання, родинного гнізда. Власне, Вал. Шевчук звертається до мотиву блудного сина, який повертається додому задля духовного оновлення. Приїзд до рідного містечка, додому, засвідчує опозиційність життя героя. Зі світу умовного, примарливого герой повертається у світ елементарний, справжній, близький. Герой-митець лише в рідних краях має можливість «пройти його [життя] пробу й очиститись, як воді через систему фільтрів, бо життя у світі мистецькому, ілюзорному, зокрема звуків, хоч які б гармонійні, досконалі та вишукані вони не були, - це тільки імітація, отож воно з часом починає міліти, мізерніти і ставати привидним, укладаючись у свої стандарти та шаблони» ${ }^{29}$.

Традиційно образ дому у Вал. Шевчука зображено в містичному аспекті. Кожна історія 3 родини Шимоновичів вражає своєю трагічністю й «оживає» 3 розповідей родичів. У довоєнний чи післявоєнний час кожна з героїнь утратила чоловіка, нареченого, а діти вмерли. Тому Станіслав у родині - єдиний «живий» чоловік дому, на якого покладається велика місія - продовження роду. Будинок, по суті, містичним чином «виселяв» чоловіків, належачи жінкам. «Це вже такий дім, чоловіки тут гості. Приречений дім» ${ }^{30}$.

Химерною видається й символіка синього кольору. Повернувшись до невеликого містечка, Станіслав розглядає затишні будинки, траву, пишну зелень, що створюють ефект звичайного та затишного дитячо-казкового світу. Навіть повітря герой сприймає іншим, прозоро-синім, що п'янить приємними відчуттями. Ж. Бодрійяр надає кольорам особливого значення як смисловому елементу середовища. Кожен колір, на думку дослідника,

${ }^{28}$ Там само. С. 356.

29 Шевчук В. Привид мертвого дому : роман-квінтет. Київ : Унів. вид-во ПУЛЬСАРИ, 2005. С. 350.

${ }^{30}$ там само. С. 371. 
наповнюється морально-психологічними смислами. Тобто зовнішній фактор має властивість впливати на суб'єкта у виборі кольору, який «підпорядкований його внутрішньому значенню» ${ }^{31}$. У такому випадку колір набуває нових семантичних ознак, що, за Ж. Бодрійяром, слугує метафорою конкретного культурного значення. Забарвлення простору в синє зумовлене зовнішнім фактором - поверненням героя додому, що на психологічному рівні забезпечує йому спокій. Відтак синій колір символізує повернення до неквапливого спокою, духовної оновленості. Холодність синього кольору зближується 3 Божественною Істиною. Намагається пізнати істину й Станіслав, коли приїздить до рідного дому.

Старовинний будинок зберігає пам'ять попередніх мешканців. Символічним тут $\epsilon$ використання фотографії як посередниці між сучасним i минулим, живим/мертвим, реальним/надприродним. Фотографії тіток нагнітають тривогу та жаль. С. Зонтаг зазначає, що фотографії втрачених рідних і близьких, зміненої до невпізнанності місцевості прив'язують людину до споминів, до оволодівання минулим. «Фотографія - це псевдоприсутність і водночас - це символ відсутності» ${ }^{32}$. Збережені фотографії функціонують як портал зі світу потойбічного у світ реальний. Зображення померлих дітей тітки Марії, iї чоловіка нагадують героїні про втрачену родину. Зримими вони постають лише в снах героїні. «Вони могли жити в цьому домі чітко видимими привидами» ${ }^{33}$. Засинаючи, жінка зустрічається 3 власною родиною. 3. Фройд стверджує, що занурення в сон відмежовує людину від зовнішнього світу. Це зворотний процес, коли людина повертається до первісного стану, до свого народження, внутрішньоутробного існування. На думку психолога, сон має бути позбавлений сновидінь, в іншому випадку «ми не досягаємо стану абсолютного спокою» ${ }^{34}$. Фотографія тут функціонує як душевний збудник. Марія прагне до ірреального, щоб надати сенсу своєму життю.

Зовсім по-іншому сприймає фотографії тітка Віра. Нещаслива в коханні, розлуку з авантюрними залицяльниками героїня «архівувала» тоді, коли купувала рамочку й уставляла до неї фотокартку колишнього чоловіка. Приватним ритуалом героїня сигналізувала прощання із

${ }^{31}$ Бодрийяр Ж. Система вещей / пер. с фр. и сопров. статья С. Зенкина. Москва : Рудомино, 1999. С. 35.

32 Сонтаг С. О фотографии / пер. с англ. В. Голышева. Москва : Ад Маргинем Пресc, 2013. С. 29.

${ }^{33}$ Шевчук В. Привид мертвого дому : роман-квінтет. Київ : Унів. вид-во ПУЛЬСАРИ, 2005. С. 319.

${ }^{34}$ Фрейд 3. Введение в психоанализ / пер. с нем. Г.В. Барышниковой. Харьков : Книжный Клуб «Клуб Семейного Досуга»; Белгород : ООО «Книжный клуб «Клуб семейного досуга», 2015. С. 83. 
коханням, а «черговий коханець переходив у світ тіней, що було недалеко від істини, бо він переходив у світ тіней тільки для неї і цього дому, отже, не мало значення, чи він топче ряст, чи вже упокоївся» ${ }^{35}$. Зберігає фотографії як пам'ять минулого й тітка Настуся. Удається до цього й Станіслав. У незвичний містичний спосіб у сні-маренні герою дається можливість сфотографувати родину, рідних, близьких, людей із минулого i теперішнього. Сфотографувати - значить запам'ятати, закарбувати в пам'яті весь рід. «Не розстріляти своєю зневагою, не убити забуттям, а сфо-то-гра-фу-ва-ти! Тобто відбити собі наш образ у душі» ${ }^{36}$. Запам'ятовуючи в пам'яті фотографоване, Станіслав стає відповідальним перед світом. На думку С. Зонтаг, фотограф у такому разі оволодіває знаннями, а відтак одержує силу перед світом.

Простір околичного життя підштовхує Станіслава до спогадів, повернення в дитинство, юність, нещасливе кохання, до пригадування родинного кола. Піддаючись споминам, герой стає сентиментальним, розчуленим. Споглядання будинків, неба, хмар, дерев зароджує в душі героя відчуття - бажання створити нові музичні композиції. «Отож і зараз прийшла до нього така музика, від чого на серці стало по-весняному тепло, адже відчути подібний настрій, в'їджаючи в рідне місто, - це пізнати сокровенне, яке на публіку не виставляється» ${ }^{37}$. Нагадує герою про перше кохання й альтанка на подвір'ї родинного будинку. Викарбувані ініціали Леоніди символізують сентиментальну радість минулого, а краєвиди занурюють у вир спогадів любовних зустрічей.

Ідеальним місцем задля утримування в пам'яті хаотичних клаптів спогадів є старий порослий сад. Вал. Шевчук наділяє сад ідилічними характеристиками. Це простір, у якому зупинено час, квітне юність, оманливість видається за реальність, а для втікачів, мандрівників (паралель зі Станіславом) - це місце-домівка. Для Станіслава це альтернативне місце життя, де після метушні великого міста можна повернутися «у світ простих речей та понять, необхідних для елементарного існування й елементарних радощів, якими наповнюється старість» $^{38}$.

Тему життя на околиці Вал. Шевчук розвиває й у четвертому «холі» під назвою «Придивися до світу». Перша частина «Картина перша. Без рамки на голій стіні» присвячена оповідям про дитинство, дитячим пригодам, пізнанню світу малого хлопця. Письменник залишається

35 Шевчук В. Привид мертвого дому : роман-квінтет. Київ : Унів. вид-во ПУЛЬСАРИ, 2005. С. 354.

36 Шевчук В. Привид мертвого дому : роман-квінтет. Київ : Унів. вид-во ПУЛЬСАРИ, 2005. С. 374.

${ }^{37}$ там само. С. 383.

${ }^{38}$ Там само. С. 298. 
вірним власному баченню. Центральним місцем подій тут постає відмежована від міста територія, долина біля річки. У такому світі хлопчик пізнає закони життя, захоплюється батьківською мудрістю, спостерігає за світом дорослих, навчається самоаналізу власних дій і вчинків, спостережливості. В уявленнях малого хлопця реальний світ набуває й особливостей світу містичного. Задля розуміння істинності, просторових широт околиці герой Вал. Шевчука розмежовує світ на свій та інший. На переконання М. Гайдегтера, сутність істини виявляється між проявом і приховуванням, що від початку свого існування протистоять одне одному. Відкриваючи для себе світ, герой підсвідомо сперечається зі світом. Філософ стверджує: «Сутність істини - це само по собі передбачувана суперечка за відкриту середину, куди вступає та звідки, установлюючись усередині самого себе, виступає усе суще» ${ }^{39}$.

Родинний дім, подвір'я, порослий сад створюють простір, що сприймається героєм по-різному. Вагомого значення надається образу дому. Вал. Шевчук зображує будинок, із яким пов'язана самотність, родинна роз'єднаність. Кожен із мешканців будинку $є$ самотнім і певним чином намагається собі допомогти. Батько хлопчика шукає відраду в чарці та власних афоризмах, мати - у скаргах на здоров'я та життя, баба Ганя - у їжі, бабця - у ворожому ставленні до світу, а хлопчик Толик - у татковій халабуді. Тримає всіх разом будинок, що зберігає історію всіх мешканців.

\section{3. Чужий простір як історія ностальгії}

Відчуваючи батьківську підтримку, мудрість, хлопчик упевнено дошукується істин. На подвір'ї приватного мешкання Толик почувається захищено, розвивається як особистість. Натомість хлопця позбавлено впливів зовнішнього світу. «Світ поза двором для мене не існував» ${ }^{40}$. Усе, що існує поза домівкою, уявляється хлопцю містичним. Власне, такою постає біла стежка, що у творчості Вал. Шевчука слугує передусім декорацією, де відбуваються важливі зміни в житті героїв: усвідомлення нового («Привид мертвого дому»), романтика дитячих пригод («Стежка в траві. Житомирська сага»), ностальгічне повернення в минуле («Роман юрби»). Так, у романі «Привид мертвого дому» Вал. Шевчук звертається до переказів, надаючи стежці історичного значення. Функціонуючи як галявина, географічна місцина зазнає впливу внаслідок людського втручання. Відтак у світосприйнятті

39 Хайдеггер М. Исток художественного творения. Хайдеггер М. Исток художественного творения: избранные работы разных лет/ пер. с нем. А.В. Михайлова. Москва : Академический проект, 2008. С. 167.

40 Шевчук В. Привид мертвого дому : роман-квінтет. Київ : Унів. вид-во ПУЛЬСАРИ, 2005. С. 385. 
Толика це химерний світ із купою сміття, порослий бур'яном. Світ поза домом озивається хрипкими покриками, гупаннями, тріщанням, лайкою, неприємними людьми. Подібним постає й порослий бур'яном сад. Його запущеність символізує тяжке життя родини, а вужі та гадюки - родинні суперечки, хвороби, утрати. Для безпечного існування на просторах околиці фантазія Толика змоделювала в дитячій свідомості неіснуючу молоду жінку, матір, уявна присутність якої надає хлопцю фізичної сили й захисту від химерних створінь.

Простір поза домом - порослі хащі, стежка, сад - сприймається хлопцем як щось потойбічне. Це Інший, непривабливий світ. В інтерпретації Р. Барта простір поза домом неорганізований, усе існує в бездиханному вигляді. Уявлення хлопця про світ постають не чіткими та не цілком сформованими. Повне конструювання околичного простору формуватиметься в уявленнях героя лише в процесі пізнання великого світу. На думку М. Мерло-Понті, максимально чітке сприйняття дії визначає перцептивний грунт, основу життя, середовище, у якому співіснують тіло та світ. Філософ стверджує: «Моє тіло впливає на світ, коли моє сприйняття пропонує мені по можливості різноманітне та чітко виражене видовище й коли мої моторні інтенції в процесі їх розгортання отримують від світу ті відповіді, на які вони очікують» ${ }^{41}$. Візуальний простір поза домом ідентифіковано героєм як іншовимірне, нереальне через відсутність можливості жити в ньому, осягати його принади й обопільно співіснувати 3 ним. Сдиним затишним і сокровенним місцем для хлопця $є$ батькова халабуда.

Халабуда як відокремлена місцина 3 різними речами виступає в романі замінником дому. Це затишний простір, у якому син і батько почуваються смиренно, спокійно, захищено, радіючи кожній проведеній там хвилині. По суті, це скарбниця, де зберігаються найдорогоцінніші речі героїв: інгалятори-пістолети, дитячі та дорослі книжки, друкарська машинка як нагадування нереалізованої письменницької мрії. Зображаючи халабуду, Вал. Шевчук наголошує на особливому родинному зв'язку, що існує між батьками та дітьми. «Сдине місце, де я міг сховатися, - це таткова халабуда. Там густо пахне тютюновим димом і духом самотнього чоловіка, адже татко влітку в хаті не жив, та й узимку 3 мамою не спав, ніби вони й справді не чоловік і не жінка. Запах халабуди, однак, був мені приємний. Міг залізти в татковий барліг, забратися під ватяну ковдру, бо татко вкривався тільки ватяною ковдрою, й читати хоч би півдня, хоч би й цілий день» ${ }^{42}$.

41 Мерло-Понти М. Феноменология восприятия / пер. с фр., под ред. И.С. Вдовиной, С.Л. Фокина. Санкт-Петербург : Ювента ; Наука, 1999. С. 322.

42 Шевчук В. Привид мертвого дому : роман-квінтет. Київ : Унів. вид-во ПУЛЬСАРИ, 2005. С. 401. 
Пізнання дитиною дійсності - традиційний сюжетний компонент Шевчукової романістики. Світогляд дитини й дитячий світ надзвичайно цікавий для прозаїка. У творчій спадщині письменника важливо, щоб дитина почувалася щасливою серед світу дорослих. Вал. Шевчук акцентує увагу й на самотності. У великому світі Толик проживає щасливу дитячу самотність. Самотніми почуваються й дорослі чоловіки, які у великому місті намагаються віднайти своє призначення. Саме такими постають герої другої частини холу «Картина друга. Зимова, з приміським лісом».

В урбаністичному просторі персонажі хочуть позбавитися внутрішньої порожнечі, натомість досягти стану спокою та гармонії зі світом. На тлі київського зимового пейзажу герої вирушають у невеличку мандрівку. Прямуючи до околиці Києва, вони зустрічають різних людей. Розповідаючи про дивакуваті зустрічі, письменник вдається до містифікації, наділяючи мандрівку казково-пригодницькими елементами. Сприяє фантастичній дійсності також і деталь людського помешкання - вікно, що світиться. «Величезна кількість вікон, натиканих густо на різній висоті, і ми справді пришвидшили ходу. Ми пришвидшили ходу, бо щось було в цій ночі фантастичне, власне, фантасмагоричне, незрозуміле, затамоване, що робило нас маленькими й загубленими» ${ }^{43}$. Г. Башляр акцентував свою увагу на такому елементі, бо хижка, що випромінює світло, зажди спонукає до таємниці, секрету. Мандруючи Києвом, герої-брати спроектували образи подорожніх, а також окремі міські об'єкти, «макрорівні деталей навколишнього середовища» ${ }^{44}$. Рух Києвом забезпечує оволодіння простором, і його сприйняття залежить від самих мандрів. На думку М. Мерло-Понті, рух у просторі постає у вигляді абсолюту за умови міцних знань, а також колишньої потаємності. Головний показник - чітка орієнтація у світі. «Відносність руху скеровується до нашої здібності змінювати місце в межах великого світу» ${ }^{45}$. Буття в місті передбачає рух. Унаслідок вивчення міських пейзажів отримані знання доповнюють нашу свідомість. Взаємодію тілесного досвіду міського простору та свідомості розглядає М. Кінгвелл, визначаючи характер цих відношень. «Свідомість формує міста. Вони будують місця за результатами людської уяви та планування... Місто й формує свідомість, ставши місцем нашого

43 Шевчук В. Привид мертвого дому : роман-квінтет. Київ : Унів. вид-во ПУЛЬСАРИ, 2005. С. 483.

${ }^{44}$ Wasiak J. Being-in-the-City: A Phenomenological Approach to Technological Experience. Culture Unbound: Journal of Current Cultural Research. 2009. Vol. 1. P. 359.

45 Мерло-Понти М. Феноменология восприятия / пер. с фр., под ред. И.С. Вдовиной, С.Л. Фокина. Санкт-Петербург : Ювента ; Наука, 1999. С. 361. 
проживання та занять, улюблених справ. Вони розміщують наші думки» ${ }^{46}$.

Самотність героїв у великому світі означує і їхнє помешкання. Квартири оповідача й Анатолія Сиротюка - два різні світи, яким властива замкненість і закритість. Однокімнатна квартира створює затишок звичного життя, «це не житло нормальної людини, а нора, викладена стосами книжок» ${ }^{47}$. Ущерть забите книжками житло навіює відчуття спокою та комфорту, а процес читання книжок дає герою гарантію подорожі до іншого світу. Цим самим герой посилює одноманітність власного життя, не вносячи жодних коректив. Самотність породжує внутрішню порожнечу, розсіюючи «шматки неживого простору». Тому герою важливо призвичаїтися до реального світу й віднайти в ньому духовну рівновагу.

Перебуваючи за межами рідного дому, оповідач із п'ятого холу «Колапсоїд» віддається споминам. У його уяві постають різнобарвні краєвиди, батьківська хата, садок, подвір'я, що в кінцевому розумінні викликало в героя стан внутрішньої розтрощеності. Мотивував героя до спогадів-роздумів батьківський лист, де йшлося про знесення їхнього родинного будинку. Настрій наратора цілком залежний від неприємної новини. Герой не наважується зруйнувати минуле, переживає за реальне існування/виживання речей із минулого, адже родинне помешкання спонукає до приємних спогадів про батька та матір. Це яскраві спогади, яких герой твору не має бажання позбуватися. М. Альбвакс указує на збереження в людині неясних уявлень минулого внутрішнього життя. Реконструюючи минуле, повторюючи його в пам'яті, людина виражає ідею постійності, власної самості. Герой твору виявляє здатність до підтримування в пам'яті конкретного наративу історії власної родини.

У романі постає образ героя-втікача, який намагається втекти від світу зовнішнього та власного, внутрішнього, позбавитися страху. За 3. Фройдом, ретельний аналіз страху виявляє готовність до можливої небезпеки, через що важливо підтримувати завищену сенсорну увагу та моторне напруження. Стає зрозумілою й причина дискомфорту головного героя серед відкритого простору. Постійне сенсорне відчуття навколишнього середовища відомий психолог визнає як велику перевагу, у разі відсутності якої можуть статися серйозні та непередбачувані наслідки, стверджуючи, що бути готовим до страху доцільно. Отримавши листа від батьків, наратор жахається можливого знесення старого будинку. У такому випадку 3. Фройд переконаний, що

${ }^{46}$ Kingwell M. Concrete Reveries: Consciousness and the City. Toronto : Viking Adult, 2008. P. 136.

47 Шевчук В. Привид мертвого дому : роман-квінтет. Київ : Унів. вид-во ПУЛЬСАРИ, 2005. С. 459. 
переляк «має особливий сенс, а конкретно характеризує дію небезпеки» $^{48}$, тому й виникнення в героя почуття страху перед світом $\epsilon$ своєрідним захистом від отриманої новини.

Герой обриває зв'язок із сучасним і минулим (роботою, квартирою, родичами, батьківською хатою, яблунями, дорогами), а відтак «пускає в себе часточку власної смерті» ${ }^{49}$. Власне письменник і наголошує на колапсі, коли людське єство піддається руйнації зсередини, «і душа від того обсновується павутиною, безконечною ниткою із бабиного літа» ${ }^{50}$.

\section{ВИСНОВКИ}

Вал. Шевчук акцентує увагу на проблемних речах, що руйнують душевний спокій людини. Письменнику важливо розібратися у внутрішніх суперечностях своїх героїв, у тому, що призводить їх до душевної спустошеності. Цікавим тут постає зображення зовнішнього/ відкритого простору, його впливу на Шевчукових героїв. Відкритий простір віддзеркалює настрій, переживання, думки героїв твору. Наратор, який намагається зрозуміти причини виникнення колапсів у власному житті, у відкритому просторі відчуває дискомфорт. Дивлячись на дерева, герой вдається до роздумів про життя і смерть, тим самим переживає власну приреченість. Відтак душа наповнюється незбагненим жалем і болем. Зображення припорошеного снігом парку відбиває внутрішній стан Шевчукового героя. Простір парку функціонує в романі як невпорядкована мозаїка, що навіює плутанину в думках. Також у відкритому просторі душа героя тьмяніє, утрачає життєдайне джерело, стимул. Йому важливо уникати простору великого світу, тому він і проїжджає повз власну зупинку. Усередині ж самого вагона герой займається перепрофілюванням навколишнього середовища. «Окрім того, дивився за вікно, а повітря здавалося надміру сіре. Здавалося, розчиняється в ньому земля і підходить драглистим киселем аж над будинки. Не мав сили зрушити в собі цього настрою. Тож i проїхав зупинку» ${ }^{51}$. В урбаністичному просторі оповідач займається «синтетичним виробництвом», що, за Ж. Бодрійяром, передбачає звільнення звичайних речей (простору) від природної символіки. У такому випадку речі (простір) стають поліморфними, «більш високого ступеня абстракції, де виявляється можливість

${ }^{48}$ Фрейд 3. Введение в психоанализ / пер. с нем. Г.В. Барышниковой. Харьков : Книжный Клуб «Клуб Семейного Досуга»; Белгород : ООО «Книжный клуб «Клуб семейного досуга», 2015. С. 397.

49 Шевчук В. Привид мертвого дому : роман-квінтет. Київ : Унів. вид-во ПУЛЬСАРИ, 2005. С. 508.

${ }^{50}$ Там само. С. 508.

51 Шевчук В. Привид мертвого дому : роман-квінтет. Київ : Унів. вид-во ПУЛЬСАРИ, 2005. С. 513. 
усеосяжної асоціативної гри речей» ${ }^{52}$. Через уявну трансформацію простору побачене героєм середовище апелює до формальної опозиції реальний/ірреальний, справжній/вигаданий, натуральний/штучний.

Погіршення душевного стану спричинили внутрішні колізії, зневагу до себе, боротьбу з юрбою та містом, ворогами та рідними. Герою важливе відсторонення від світу, адже реальне життя видається почварним i лихим. Лише зі зміною основного місця існування (міського) відбувається й прояснення розуму героя. Повернення до батьківського гнізда, вулиць, що апелюють до дитинства, роз'яснює причини душевної спустошеності. Сенс філософічності прози Вал. Шевчука концентрується в понятті «рідний дім»: із руйнацією дому руйнується й людина, стає пусткою, адже дім - це «жива істота, що дихає, мислить, руйнується, відновлюється й має свою душу, а душа, як сказав мудрець, «справді $є$ форма, яка дає буття природному тілу, що має різні частини і здатності до буття» ${ }^{53}$.

\section{АНОТАЦІЯ}

У дослідженні проаналізовано твори Вал. Шевчука на предмет художнього простору як репрезентантів пам'яті та історії. Авторський художній простір романістики 2000 -х рр. набуває різних семантичних значень: реального та ірреального, справжнього та вигаданого, натурального та штучного. Сприяють цьому топоси провінційного середовища: вулиці, хащі, стежки, халабуди, подвір'я, сад тощо. Окремий мікрокосм усієї творчості Вал. Шевчука - образ Дому, як пам'ять про ідилічне життя за межами урбанізованого простору. 3'ясовано, що околичний простір, і дім зокрема, апелює до приємних спогадів і родинних історій, що у великому місті часто забуваються або стираються з пам'яті.

\section{ЛIТЕРАТУРА}

1. Wirth L. Urbanism as a way of life. The American journal of sociology. 1938. Vol.44. P. 1-24. URL: https://www.uc.edu/cdc/ urban_database/fall03-readings/urbanism_as_a_way.pdf (дата звернення: 10.11.2020).

2. Шевчук В. Стежка в траві. Житомирська сага : у 2 т. Харків : Фоліо, 1994. Т. 1.494 с.

3. Корогодський Р. Втеча від самотності, або Апологія рідного дому. Шевчук В. Стежка в траві. Житомирська сага : у 2 т. Харків : Фоліо, 1994. Т. 1. С. 5-48.

\footnotetext{
${ }^{52}$ Бодрийяр Ж. Система вещей / пер. с фр. и сопров. статья С. Зенкина. Москва : Рудомино, 1999. С. 44.

53 Шевчук В. Привид мертвого дому : роман-квінтет. Київ : Унів. вид-во ПУЛЬСАРИ, 2005. С. 592.
} 
4. Шевчук В. Стежка в траві. Житомирська сага : у 2 т. Харків : Фоліо, 1994. Т. 2. 526 с.

5. Хаттон П. История как искусство памяти. Санкт-Петербург : Владимир Даль, 2004. 424 с.

6. Шевчук В. Роман юрби: хроніка «безперспективної» вулиці (1972-1991) / передм. Л. Тарнашинської. Київ : Унів. вид-во ПУЛЬСАРИ, 2009. 622 с.

7. Хайдеггер М. Проселок. Исток художественного творения: избранные работы разных лет / пер. с нем. А.В. Михайлова. Москва : Академический проект, 2008. С. 391-394.

8. Башляр Г. Избранное : Поэтика пространства / пер. с фр. Н.В. Кисловой, Г.В. Волковой, М.Ю. Михеева. Москва : Российская политическая энциклопедия (РОССПЭН), 2004. 376 с.

9. Сонтаг С. О фотографии / пер. с англ. В. Голышева. Москва : Ад Маргинем Пресс, 2013. 272 с.

10. Бодрийяр Ж. Система вещей / пер. с фр. и сопров. статья С. Зенкина. Москва : Рудомино, 1999. 224 с.

11. Фрейд 3. Введение в психоанализ / пер. с нем. Г.В. Барышниковой. Харьков : Книжный Клуб «Клуб Семейного Досуга»; Белгород : ООО «Книжный клуб «Клуб семейного досуга», 2015. $480 \mathrm{c}$.

12. Хайдеггер М. Исток художественного творения. Хайдегzер $M$. Исток художественного творения : избранные работы разных лет / пер. с нем. А.В. Михайлова. Москва : Академический проект, 2008. C. 76-256.

13. Мерло-Понти М. Феноменология восприятия / пер. с фр., под ред. И.С. Вдовиной, С.Л. Фокина. Санкт-Петербург : Ювента ; Наука, 1999. $608 \mathrm{c}$.

14. Wasiak J. Being-in-the-City: A Phenomenological Approach to Technological Experience. Culture Unbound: Journal of Current Cultural Research. 2009. Vol. 1. P. 349-366.

15. Kingwell M. Concrete Reveries: Consciousness and the City. Toronto : Viking Adult, 2008. 256 p.

\section{Information about the author:} Hryshchenko O. V.,

Candidate of Philological Sciences, Associate Professor at the Department of Journalism Pylyp Orlyk International Classical University 12, Karla Libknekhta str., Mykolaiv, 54000, Ukraine 